Gulawentah: Jurnal Studi Sosial

Vol. 3, No. 1, Juni 2018, hal: 61-67

ISSN 2528-6293 (Print); ISSN 2528-6871 (Online)

Tersedia Online: http://e-journal.unipma.ac.id/index.php/gulawentah

\title{
Sikap dan Tindakan Masyarakat Terhadap Orang Gila dan Kampung Gila Desa Paringan Kecamatan Jenangan Kabupaten Ponorogo
}

\author{
Muh. Aziz Widayat
}

SDN 2 Nglayang, Ds. Nglayang Jenangan 63492 Ponorogo, Indonesia

Email: widayataziz@yahoo.co.id

\begin{abstract}
Abstrak
Penelitian ini bertujuan menganalisis dan mendeskripsikan sikap dan tindakan masyarakat terhadap orang gila dan kampung gila Desa Paringan Kecamatan Jenangan Kabupaten Ponorogoa. Penelitian dilaksanakan selama 6 bulan dengan menggunakan pendekatan kualitatif dan metode field research (penelitian lapangan). Informan ditentukan secara purposive sampling. Pengumpulan datanya dengan teknik observasi, wawancara, dokumentasi. Untuk mendapatkan keabsahan data menggunakan triangulasi sumber. Sedangkan teknik analisis datanya dengan model analisis interaktif Miles dan Huberman. Dari penelitian yang dilakukan diperoleh hasil bahwa sikap masyarakat Desa Paringan walaupun berat namun menerima warga yang mengalami gangguan jiwa (gila). Mereka berusaha melakukan berbagai tindakan untuk membantunya agar warga yang mengalami gangguan jiwa diperlakukan secara manusiawi. Selain itu, untuk mengelimir stigma negatif desanya, masyarakat beserta aparatur pemerintahan desa melaksanakan kegiatan diantaranya; (1) memberdayakan sumber daya alam sebagai destinasi wisata, (2) memberdayaakan ekonomi masyarakat dengan pengolahan diversifikasi makanan ringan.
\end{abstract}

Kata kunci: kampung gila; sikap; tindakan masyarakat

\section{People's Attitudes and Actions to Mental Ilness People and Kampong Mental Ilness of Paringan Village, Jenangan District, Ponorogo Regency}

\begin{abstract}
The study aims at analysing and describing people's attitudes and actions to mental ilness and kampong of mental illness of Paringan Village, Jenangan District, Ponorogo Regency. It was conducted during six months by using qualitative research approach and field research method. The informants were selected through purposive sampling. Data were collected by using observation, interview, and documentation. The data, then were verified by using sources triangulation. Further, the data were analyzed by operating Miles and Huberman's interactive analysis model. The results of the study show that no matter how hard it is, the people of Paringan village try to accept the existence of mental illness people in their village. They keep making some actions in order to help the mental illness people to be treated humanely. Besides, to eliminate negative stigma on their village, the people and village government officials conduct some activities, namely; (1) enabling village natural resources as tourism destination and (2) enabling people's economy through having diverness to produce snacks.
\end{abstract}

Keywords: kampong of mental illness people; attitudes; actions

DOI: 10.25273/gulawentah.v3i1.2829

Copyright @ 2018 Universitas PGRI Madiun

All rights reserved. 


\section{Pendahuluan}

Kabupaten Ponorogo terkenal dengan kesenian khasnya yang mendunia yaitu Reyog. Ponorogo juga dikenal sebagai kota santri dengan sejumlah pesantren, termasuk pesantren yang bereputasi internasional seperti Pondok Pesantren Modern Gontor yang telah banyak melahirkan tokoh-tokoh bereputasi nasional maupun internasional. Di tengah kekayaan budaya dan modal sosial bereputasi nasional dan internasional, Ponorogo memiliki sisi lain yang fenomenal dan unik yaitu terdapatnya desa yang dilabeli dengan sebutan "kampung gila". Desa tersebut yaitu Desa Paringan Kecamatan Jenangan. Berdasarkan penelitian pendahuluan pada bulan Agustus sampai Oktober 2016, ditemukan fakta bahwa desa tersebut terdapat 60 orang yang mengalami gangguan jiwa dengan berbagai rentang usia. Bapeda Ponorgo (2016) menyatakan bahwa pada tahun 2011, masyarakat Ponorogo dikejutkan dengan berita tentang terdapatnya "kampung gila" yang terletak di Desa Paringan Kecamatan Jenangan Kabupaten Ponorogo. Berdasarkan survei awal oleh Rumah Sakit Jiwa Malang dan Pemerintah Daerah Ponorogo yang dilakukan pada tanggal 31 Maret 2011 jumlah penderita gangguan jiwa di Desa Paringan sebanyak 60 jiwa. Jumlah ini tergolong besar mengingat jumlah penduduk desa yang mencapai 6000 jiwa sehingga jumlah perbandingan antara warga yang terkena gangguan jiwa dengan warga yang sehat adalah 1:100.

Stigma negatif tersebut di atas menjadi beban tersendiri bagi masyarakat Paringan khususnya dan pemerintah daerah Kabupaten Ponorogo pada umumnya. Belum lagi fakta yang membuktikan bahwa di "kampung gila" tersebut banyak sekali penderita ODS (Orang Dengan Skizofrenia) yang mendapat perlakuan diskriminatif dari pihak keluarga dan lingkungan dalam bentuk pemasungan. Sehingga timbul berbagai pertanyaan terutama bagaimana sikap dan tindakan warga masyarakat terhadap orang gila di Desa Paringan Kecamatan Jenangan Kabupaten Ponorogo dan bagaimana upaya menyikapi fenomrna tersebut? Adapun tujuan penelitian ini yaitu menganalisis dan mendeskripsikan sikap dan tindakan masyarakat Paringan Jenangan Ponorogo terhadap orang gila dan stigma desa sebagai "kampung gila"

Strickland (dalam Hanurawan, 2012:64) menyatakan sikap adalah predisposisi atau kecenderungan untuk memberikan respon secara kognitif, emosi, dan perilaku yang diarahkan pada suatu objek, pribadi, dan situasi khusus dalam cara-cara tertentu. Ahmadi (dalam Hanif,2014) juga menyampaikan bahwa sikap merupakan tingkatan kecenderungan yang bersifat positif atau negatif yang berhubungan dengan objek. Objek di sini adalah warga masyarakat yang mengalami gangguan jiwa. Selain dua pakar tersebut, masih banyak lagi pakar yang mendefinisikan tentang sikap dengan berbagai sudut pandang sehingga dapat ditarik benang merahnya, bahwa yang dimaksud sikap adalah kesiapan merespon yang sifatnya positif atau negatif terhadap objek atau situasi secara konsisten. Sikap positif merupakan sikap yang menunjukkan atau memperlihatkan menerima, mengakui, menyetujui, serta melaksanakan norma-norma yang berlaku. Sedangkan sikap negatif merupakan sikap yang menunjukkan atau memperlihatkan penolakan atau tidak menyetujui, dan tidak melaksanakan norma-norma yang berlaku (Ahmadi, 2007:153).

Sikap sebagaimana disampaikan di atas merupakan kesadaran individu yang menentukan perbuatan yang nyata dalam kegiatan-kegiatan sosial. Sehingga yang dimaksud sikap masyarakat atau sosial yaitu sikap orang-orang sekelompoknya terhadap objek sosial (banyak orang dalam kelompok) dan dinyatakan berulang-ulang. Sikap sosial ini ditandai dengan subjeknya adalah orang-orang dalam kelompoknya, objeknya sekelompok orang, dan frekuensinya berulang-ulang. W.J. Thomas dalam Ahmadi 
(2007:152-153) menyampaikan, bahwa sikap masyarakat ini sebagai suatu kesadaran yang menentukan perbuatan-perbuatan yang nyata atau mungkin yang akan terjadi di dalam kegiatan-kegiatan sosial.

Travers dan Gagne (dalam Ahmadi, 2007:151) menyampaikan, bahwa sikap melibatkan tiga komponen yang saling berhubungan. Ketiga komponen sikap tersebut, yaitu: (1) Kognitif berupa pengolahan, pengalaman, dan keyakinan serta harapan-harapan individu tentang objek tertentu, (2) Afektif; berwujud proses yang menyangkut perasaanperasaan tertentu seperti simpati, antipati dan sebagainya yang ditujukan kepada objek tertentu, dan (3) Konatif berwujud proses tendensi/kecenderungan berbuat sesuatu terhadap suatu objek. Misalnya kecenderungan memberi pertolongan, menjauhkan diri, dan sebagainya.

Sikap terbentuk dari proses belajar. Hal ini sebagaimana yang disampaikan Rahman (2013:131-132), bahwa secara umum para pakar psikologi sosial menyakini bahwa sikap merupakan hasil dari proses belajar. Sedangkan sikap-sikapnya yang baru terbentuk setelah melakukan kontak sosial dengan lingkungannya. Proses belajar yang dimaksud seperti mengamati orang lain (belajar sosial), proses asosiasi, pengalaman langsung, dan pengamatan terhadap perilakunya sendiri,

Sikap memiliki berfungsi bagi individu atau sekolompok orang, antara lain: sebagai pemandu mencapai tujuan yang diinginkan dan menghindari hasil yang tidak diinginkan, memelihara dan meningkatkan harga diri, alat mengeskpresikan nilai-nilai dan konsep diri (memperkenalkan nilai-nilai atau keyakinan terhadap orang lain), dan lain sebagainya (Rahman, 2013:129-130).

Banyak pendapat yang menerangkan tentang faktor-faktor yang mempengaruhi sikap, namun menurut Walgito (dalam Hanif, 2014) hanya ada beberapa saja yang dianggap penting dan determinan, yaitu: (1) Faktor fisiologis. Faktor fisiologis sangat berperan penting bagi individu karena di sinilah sikap individu mulai terbentuk. Misalkan saja seseorang yang tidak mempunyai kesempurnaan fisik (cacat fisik) akan mempunyai tingkat kepercayaan diri yang berbeda dengan seseorang yang normal. Seseorang cacat fisik cenderung kurang percaya diri dan menutup diri dari orang lain, (2) Faktor pengalaman langsung terhadap objek sikap. Faktor pengalaman pada individu memberikan pengajaran dan pengetahuan pada seseorang. Dengan pengalaman seseorang akan mengetahui bagaimana menentukan sikap yang baik/buruk. Misalkan pada seorang yang punya banyak pengalaman berharga, bisa saja ia menjadi orang yang bijaksana atau bahkan menjadi orang yang sombong, (3) Faktor situasi. Faktor situasi dapat dikatakan sebagai peluang untuk menentukan dan membentuk sikap. Dalam setiap situasi individu harus mampu berdaptasi karena jika tidak dikhawatirkan akan muncul sikap-sikap yang kurang pantas untuk ditampilkan dalam masyarakat, (4) Faktor norma dalam kehidupan dapat memberikan batasan-batasan, dalam hubungannya dengan sikap individu adalah sikap yang timbul dapat bervariasi, (5) Faktor kerangka acuan dalam sikap seseorang, karena kerangka acuan akan berperan terhadap objek sikap. Bila kerangka acuan tidak sesuai dengan objek sikap, maka orang akan mempunyai sikap yang negatif terhadap objek sikap tersebut, (6) Faktor komunikasi sosial. Faktor ini menjadi faktor determinan sikap seseorang.

Sikap ini mempredisposisi tindakan yang ditampilkan oleh sekelompok orang (a group behavior) dalam situasi sosial dengan manusia yang lain merupakan satu pola yang relatif menetap yang diperlihatkan oleh individu di dalam interaksinya dengan orang lain. Individu dituntut mampu menyesuaikan diri dengan beragam lingkungan baik lingkungan keluarga dan lingkungan masyarakat. Lingkungan masyarakat membina hubungan 
dengan warga masyarakat yang datang dari berbagai ragam keluarga dengan warna sosial yang beragam. Oleh karena itu sosialisasi yang dilakukan oleh individu di masyarakat akan tergantung dari kemampuan individu dalam menyesuaikan diri dengan berbagai kegiatan yang ada di masyarakat (Simon dalam Johnson, 1988:76). Keseluruhan tindakan dan hubungan timbal-balik dalam suatu kelompok, membentuk sistem sosial kelompok itu, dan di luar batas ini ada lingkungan dimana kelompok itu ada dan dengan kelompok yang mana harus menyukai dirinya. Suatu gambaran mengenai lingkungan kelompok meliputi lingkungan fisik, pola kepribadian dan sikap anggota kelompok yang mereka bawa dalam kelompok itu, serta konteks organisasi atau budaya yang lebih luas dimana kelompok itu berfungsi. Tindakan yang ditampakkan oleh sekelompok orang pada saat berinterelasi sosial dengan lingkungan tersebut terdapat proses saling merespon, saling mempengaruhi, serta saling menyesuaikan diri dengan lingkungan sosialnya. Dengan demikian yang dimaksud tindakan masyarakat dalam penelitian ini yaitu segala sesuatu bentuk tingkah laku atau aktivitas yang ditampakkan oleh kelompok warga masyarakat pada saat berinterelasi stigma negatif lingkungannya.

\section{Metode Penelitian}

Penelitian ini menggunakan pendekatan kualitatif dengan metode field research (penelitian lapangan) agar masalah atau keadaan dan juga peristiwa sebagaimana adanya sehingga hasilnya memberikan. Informan yang digunakan terdiri dari mantan penderita gangguan jiwa, keluarga penderita gangguan jiwa, perangkat desa, masyarakat umum, dan non warga Desa Paringan tetapi setiap hari beraktivitas di wilayah Desa Paringan. Penentuan informan (sampel) menggunakan teknik nonprobability sampling dengan cara purposive sampling. Pengumpulan data dilakukan dengan teknik observasi, wawancara, dokumentasi. Untuk mendapatkan keabsahan data, peneliti menggunakan triangulasi sumber. Sedangkan teknik analisis datanya menggunakan model analisis interaktif Miles dan Huberman (1992). Analisis interaktif terdiri atas tiga komponen utama yaitu reduksi data, sajian data, penarikan simpulan dan verifikasi. Dalam proses ini, peneliti tetap bergerak diantara tiga komponen analisis dengan proses pengumpulan data selama proses pengumpulan data berlangsung. Kemudian sesudah pengumpulan data berakhir, peneliti bergerak diantara tiga komponen analisisnya dengan mengunakan waktu yang masih tersisa bagi penelitiannya sampai tuntas dan datanya jenuh.

\section{Hasil dan Pembahasan}

Jumlah penderita gangguan jiwa di Desa Paringan tergolong banyak. Namun demikian, pihak-pihak terkait belum mempunyai data yang valid seputar jumlah penderita gangguan jiwa. Sebagai contoh, mengacu pada data statistik pada buku Kecamatan dalam Angka 2017 yang diterbitkan oleh Badan Pusat Statistik Ponorogo, disebutkan bahwa jumlah warga Desa Paringan yang mengalami cacat sebanyak 37 orang dengan rincian: tuna netra sebanyak 8 orang, tuna rungu/tuna wicara seperti pada tabel di bawah inisebanyak 9 orang, dan tuna daksa 20 orang (BPS Ponorogo, Kecamatan Jenangan Dalam Angka 2017). Data tersebut tidak menyebut secara spesifik tentang jumlah angka orang yang penderita gangguan jiwa. Sedangkan menurut data yang dimiliki Dinas Sosial Tenaga Kerja dan Transmigrasi Kabupaten Ponorogo, jumlah warga Desa Paringan Kecamaan Jenangan Kabupaten Ponorogo yang menderita gangguan jiwa sebanyak 78 jiwa (Data Dinsosnakertrans, 2016). 
Berdasarkan hasil observasi dokumen dan wawancara diketahui bahwa jumlah penderita gangguan jiwa di Kabupaten Ponorogo secara umum ataupun Desa Paringan secara khusus mengalami penurunan dari tahun ke tahun. Data Dinas Kesehatan (Radar Ponorogo, 1 Maret 2018) menyebutkan bahwa jumlah orang dengan gangguan jiwa (ODGJ) di Kabupaten Ponorogo pada tahun 2016 sebanyak 3.080 orang. Tahun 2017 sebanyak 3.072 orang. Data yang dimiliki Kecamatan Jenangan (2017) menunjukkan bahwa jumlah orang cacat di Desa Paringan sebanyak 37 orang. Sedangkan Suwendi (Kepala Desa Paringan) menyebutkan bahwa jumlah pengidap gangguan jiwa di desanya sudah berkurang. Menurutnya, hasil pemetaan penderita gangguan jiwa tahun 2011-2015 oleh Dinas Kesehatan Ponorogo, ditemukan 72 warga mengidap gangguan jiwa. dari jumlah tersebut, 27 orang dinyatakan sembuh. Artinya hampir separo jumlah penderita. Hal senada juga diungkapkan oleh koordinator Puskesmas Pembantu Kejiwaan Paringan bahwa jumlah penderita gangguan jiwa tingkat sedang dan berat menurun.

Hasil wawancara di atas sejalan dengan hasil observasi yang menyebutkan bahwa sudah jarang terlihat orang gila lalu lalang di sekitar Balai Desa Paringan sebagaimana dulu biasa terlihat setiap hari. Hal tersebut juga dikuatkan bahwa banyak orang yang dulu dianggap gila, sekarang sudah sembuh. Sudah bersedia berkomunikasi dengan orang lain, meskipun belum dalam kelompok besar. Menurut Suwendi, awal 2018 ini jumlah penderita gangguan jiwa menurut tinggal 45 orang. Persebaran ke-45 orang penderita gangguan jiwa tersebut sebagaimana dalam table di bawah ini

Tabel 1. Style dan Fungsinya

\begin{tabular}{ccccc}
\hline Nama Dusun & Krajan & Krangkungan & Bagusan & Semambu \\
\hline Jumlah penderita & 9 & 11 & 18 & 7 \\
\hline
\end{tabular}

Masyarakat malu dan tidak nyaman dengan sebutan kampung gila karena mereka merupakan bagian dari masyarakat tersebut. Seiring dengan perjalanan waktu warga masyarakat mulai sadar. Suka atau tidak suka mereka lahir dan dibesarkan di Desa Paringan serta menjalani hidup dan kehidupannya di desa tersebut. Selain itu juga tumbuh kesadaran dan keyakinan bahwa tidak ada orangpun yang ingin menjadi gila. Orang gila itu merupakan takdir Tuhan dan ujian yang harus disikapi secara positif dengan berusaha dan berdoa. Sikap masyarakat menerima warga yang mengalami gangguan jiwa atau gila tersebut diwujudkan dalam berbagai bantuan baik moril maupun materiil. Setidaktidaknya warga masyarakat yang mengalami gangguan jiwa tersebut diperlakukan secara manusiawi.

Masyarakat juga berusaha mengelimir ketidaknyamanan akibat sebutan kampung gila tersebut dengan berbagai program atau kegiatan yang berefek positif bagi banyak pihak. Diantaranya yaitu memberikan berbagai fasilitas bantuan atau pendampingan kepada penderita atau keluarga penderita agar penderita bisa sembuh. Mereka berusaha merubah stigma negatif tersebut menjadi dampak sosial positif. Dengan mengerahkan semua potensi yang dimiliki, pemerintah desa berusaha memanfaatkan sumber daya kreatif yang dimiliki untuk merubah citra desa menjadi lebih baik. Tentunya perubahan citra tersebut harus berdampak pada peningkatan ekonomi dan martabat warga atas stigma sebagai kampung gila. Untuk itulah pemeritah desa membentuk Kelompok Sadar Wisata (Pokdarwis). Dari Pokdarwis inilah muncl usaha kreatif pemanfaaatan alam desa (Kali Kajar) untuk kegiatan wisata alam tubbing Kali Kajar desa Paringan Kecamatan Jenangan. Selain Tubbing Kali Kajar, pokdarwis juga mengelola home industry makanan 
ringan dengan brand khas Desa Paringan. Untuk mengoptimalkan sosialisasi wisata tubbing Kali Kajar dan produk lain yang ada di desa, pemerintah desa memberdayakan generasi muda kreatif dalam komunitas paringan. Komunitas ini memproduksi videovideo seputar program desa. Untuk menjaga kesehatan warga, komunitas ini juga mengelola kegiatan senam sehat bersama di lapangan desa. Akibatnya, seirin waktu, persepsi masyarakat terhadap Desa Paringan mulai bergeser, dari Kampung Gila menjadi Desa Wisata.

Pengelolaan sebutan kampung gila sebagai titik awal pemberdayaan masyarakat juga memberikan dampak positif bagi ekonomi masyarakat. Hal ini ditandai dengan munculnya wisata Tubing Kali Kajar dan produk-produk makanan ringan khas Desa Paringan. Kegiatan ekonomis ini secara tidak langsung berdampak positif bagi warga secara umum maupun keluarga penderita gangguan jiwa.

Jika dianalisa dari teori sikap dan tindakan, sikap dan tindakan warga masyarakat tersebut di atas dapat dipahami mengapa sampai hal yang luar biasa sebagai proses pencapaian pengetahuan dan proses berfikir tentang orang lain, misalkan berdasar pada ciri-ciri fisik, kualitas, bahkan pada kepribadiannya. Individu membangun gambaran tentang orang lain dalam upaya menetapkan, memungkinkan, meramalkan, dan mampu mengelola dunia sosialnya. Dalam hal ini, apabila seseorang memiliki pengetahuan tentang kecenderungan orang lain, ia akan mudah memahami perilaku orang itu di masa lalu, masa sekarang, serta dimasa akan datang. Sebagaimana diketahui bahwa dalam memahami suatu obyek, antara orang satu dengan yang lain belum tentu sama. Ada kecenderungan melihatnya dengan cara yang berbeda-beda. Perbedaan tersebut dipengaruhi oleh banyak faktor, antara lai; pengetahuan, pengalaman dan sudut pandangnya. Sikap dan tindakan bertautan juga dengan cara pandang seseorang terhadap suatu objek tertentu dengan cara yang berbeda-beda dengan menggunakan alat indera yang dimiliki, kemudian berusaha untuk menafsirkannya.

\section{Kesimpulan}

Sikap masyarakat Desa Paringan Kecamatan Jenangan Kabupaten Ponorogo walaupun berat menerima warga yang mengalami gangguan jiwa (gila). Mereka berusaha melakukan berbagai tindakan untuk membantunya agar warga yang mengalami gangguan jiwa diperlakukan secara manusiawi. Selain itu, untuk mengelimir stigma negatif desanya, masyarakat beserta beserta aparatur pemerintahan desa melaksanakan kegiatan diantaranya; (1) memberdayakan sumber daya alam sebagai destinasi wisata, (2) memberdayaakan ekonomi masyarakat dengan pengolahan diversifikasi makanan ringan.

\section{Daftar Pustaka}

Ahmadi, A. (2007). Psikologi Sosial. Jakarta: Rineka Cipta

Hanif, M. (2014). Meneropong Kampung Idiot, Perilaku Sosial Terhadap Warga Retardasi Mental Sidoharjo dan Krebet. Madiun: Institut Press IKIP PGRI Madiun 
Badan Perencana Pembangunan Daerah Kabupaten Ponorogo. (2016). Profl Kecamatan Jenangan 2016. Ponorogo: Bapeda Ponorogo

BPPS Ponorogo. (2017). Kecamatan Jenangan dalam Angka 2017. Ponorogo: BPS Ponorogo

Rahman, A.A. (2013). Psikologi Sosial, Integrasi Pengetahuan Wahyu dan Pengetahuan Empirik. Jakarta: PT RajaGrafindo Persada.

Johnson, D.P., (1998). Teori Sosiologi Klasik dan Modern, Jakarta: Gramedia

Hanurawan, F. (2012). Psikologi Sosial, Suatu Pengantar. Bandung: PT. Remaja Rosdakarya

Hawari, D. (2009). Pendekatan Holistik Pada Gangguan Jiwa Skizofrenia. Jakarta: Balai Penerbit FKUI.

Walgito, B. (2011). Teori-Teori Psikologi Sosial. Yogyakarta: Penerbit ANDI

Bappeda Ponorogo "Seminar Angka Kemiskinan dan Indeks Pembangunan Manusia Kabupaten Ponorogo di Paringan", http://bappeda.ponorogo.go.id/, Diakses 22 Agustus 2017.

Kumalasari, I. dan Utami D.. Collaborative Governance dalam Penanganan Kasus Gangguan Jiwa Di Desa Paringan Kecamatan Jenangan Kabupaten Ponorogo. Jurnal Keperawatan Jiwa. 2(1) Mei 2014; 14-23.

Miles, M.B., dan Huberman, A.M. (1992). Analisis Data Kualitatif. Jakarta: UI Press. 